Vol u m e 14 Nu m be $1 \mathrm{P}$ a ge s $58-64,22020$

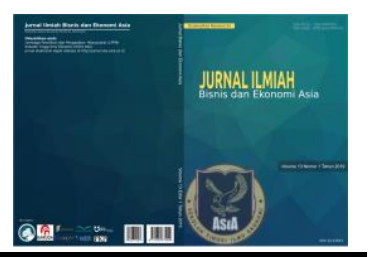

\title{
ANALISIS MODEL REKRUTMEN BERBASIS KETERAMPILAN DAN DAMPAKNYA PADA NILAI SEKOLAH DI MASYARAKAT INDUSTRI
}

\author{
Haryanto ${ }^{1 *}$; Eka Setya Budi ${ }^{2}$ \\ 1,2Universitas Islam Nahdatul Ulama Jepara, Indonesia
}

INFO ARTIKEL

DOI:10.32812/jibeka.v14i1.155

ISSN-P: 0126-1258

ISSN-E: 2620-875X

Keywords: Recruitment, School Grades, Industrial Society

Kata Kunci: Rekrutmen, Nilai

Sekolah, Masyarakat Industri

\begin{abstract}
The recruitment process is the first step for companies to get the quality workforce or employees needed by the company. The purpose of this study was to describe the skills-based recruitment model of factories in the Jepara industrial community. This survey study took the population of dropped-out children who are accepted to work at the company. Total sampling technique was apllied by considering all samples as respondents. The technique of collecting data uses questionnaire. The data collection technique uses documentation in the form of company monograph records, which includes data on the number of employees, employee education and stages of recruitment and questionnaires in the form of closed questionnaires. Data analysis techniques used qualitative descriptive interactive models Miles and Hubberman with the stages of data reduction analysis, data presentation, conclusion drawing. Stages of research include the observation phase, the problem analysis stage and needs analysis, and the research data analysis stage. The research results show that the recruitment model is conducted in two ways, internally by recruiting existing employees to fill the vacancy and external recruitment by opening job openings in print media and job site websites. This recruitment model influence the value of school to be something priceless because the recruitment or the staff selection at the company focuses on the skill, not on the scores in school certificate.
\end{abstract}

\section{ABSTRAK}

Proses rekrutmen adalah langkah pertama bagi perusahaan untuk mendapatkan tenaga kerja atau karyawan berkualitas yang dibutuhkan perusahaan. Tujuan penelitian ini adalah untuk mengetahui model rekrutmen perusahaan berbasis keterampilan di masyarakat industri Jepara. Penelitian ini termasuk jenis penelitian survey dengan populasi anak putus sekolah diterima bekerja di perusahaan. Teknik pengambilan sampel diterapkan teknik total sampling dengan menjadikan keseluruhan sampel dari jumlah responden. Dalam mengumpulkan data digunakan teknik angket. Teknik pengumpulan data menggunakan cara dokumentasi berupa catatan-catatan monografi perusahaan, yang meliputi data jumlah karyawan, pendidikan karyawan dan tahapan rekrutmen dan angket berupa berupa angket tertutup. Teknik analisis data menggunakan deskriptif kualitatif model interaktif (interactive model) Miles dan Hubberman dengan tahapan analisis reduksi data, penyajian data, penarikan kesimpulan. Tahapan penelitian meliputi tahap observasi, tahap analisis masalah dan analisis kebutuhan, dan tahap anasisis data penelitian Hasil penelitian menunjukkan bahwa model rekrutmen dilakukan dengan dua cara yaitu secara internal dengan merekrut karyawan yang sudah ada untuk mengisi kekosongan jabatan dan rekrutmen secara eksternal dengan membuka lowongan pekerjaan di media cetak serta situs web lowongan kerja. Pengaruh model rekruitmen tersebut berdampak terhadap nilai sekolah menjadi sesuatu hal yang tidak terlalu penting karena rekrutmen atau pemilihan karyawan di perusahaan didasarkan pada ketrampilan (skill), bukan pada nilai pada ijasah sekolah. 


\section{Pendahuluan}

Dalam mendapatkan sumberdaya manusia atau karyawan berkualitas sesuai dengan yang dibutuhkan, hal pertama yang harus dilakukan adalah proses rekrutmen. Rekrutmen menjadi jalan penghubung antara kebutuhan perusahaan dengan ketersediaan sumberdaya manusia atau calon karyawan di lapangan. Untuk itu, perusahaan harus memastikan terlebih dahulu indikator atau kriteria karyawan yang diinginkan sebagai pedoman dalam menjalankan proses rekrutmen dan pemilihan tenaga kerja.

Rekrutmen merupakan suatu proses mencari dan menarik individu untuk mengisi posisi tertentu dalam perusahaan (Fisher et al., 2006). Tujuan pokok proses rekrutmen yang dilakukan organisasi adalah mengidentifikasi dan mengajak tenaga potensial bergabung di organasasi tersebut (Noe et al., 2008). Berdasarkan cara penarikannya, rekrutmen terbagi menjadi dua jenis: pertama, secara internal dengan menjadikan tenaga kerja yang sudah ada, seperti kebijakan promosi jabatan; dan kedua, secara eksternal dengan mengamati keadaan ekonomi dan tenaga kerja yang ada di bursa tenaga kerja. Mondy (2010) menyatakan bahwa proses rekutmen digolongkan menjadi dua jenis, yaitu (1) sistem internal dengan menginformasikan adanya lowongan posisi atau pekerjaan pada para karyawan dan pengajuan pekerjaan sebagai langkah para karyawan yang merasa memenuhi persyaratan untuk menduduki jabatan pekerjaan tersebut dan (2) sistem eksternal dengan menggunakan sumber daya manuasi di luar organisasi seperti lembaga pendidikan, sekolah, perguruan tinggi, institusi, akademi, dan lain-lain.

PT PWI, PT Kanindo, dan PT Jeale Textile adalah perusahaan-perusahaan yang berkembang di masyarakat industri Jepara. Perusahan-perusahaan tersebut menerapkan proses seleksi yang tidak berdasarkan nilai rapor atau nilai ijasah, namun berdasarkan keterampilan (skill). Hal ini tentunya berdampak pada nilai sekolah khususnya pada masyarakat industri Jepara. Dewi menyatakan bahwa yang menjadi sorotan dalam bidang pendidikan di Indonesia adalah masalah tinggal kelas, keterlambatan belajar di pendidikan dasar, drop-out, serta keadaan lulusan yang tidak mampu melanjutkan belajar ke jenjang yang lebih tinggi (Dewi, 2014: 57). Pendidikan merupakan aspek utama dalam meningkatkan mutu sumber daya manusia saat ini dan masa depan. Banyaknya jumlah anak yang tidak melanjutkan sekolah akan menyebabkan masalah baru. Salah satu contohnya adalah permasalahan pendidikan berupa anak putus sekolah di Kecamatan Mayong Kabupaten Jepara.

Sekarang ini persoalan anak putus sekolah bukan menjadi sesuatu yang baru untuk diperbincangkan. Namun persoalan ini begitu penting dibicarakan di kalangan akademisi maupun dari kalangan umum sebab masalah ini berkaitan langsung dengan maju tidaknya suatu bangsa. Anak putus sekolah ialah anak didik yang tidak dapat menyelesaikan program belajarnya (Musfiqon, 2007:19). Melihat kondisi ini, masalah anak putus sekolah menjadi tanggung jawab seluruh elemen masyarakat baik keluarga, masyarakat maupun pemerintah. Hasil observasi awal yang dilakukan peneliti pada tahun ajaran 2017 sampai tahun ajaran 2018 menunjukkan bahwa terdapat 32 anak yang putus sekolah dijenjang pendidikan Sekolah Menengah Pertama (SMP). Hal ini dilakukan oleh anak sekolah bukan karena tidak mampu membayar biaya sekolah, ataupun tidak mampu melunasi biaya uang gedung. Namun, putus sekolah ini dikarenakan bekerja di beberapa perusahaan seiring dengan tumbuhnya perusahaan-perusahaan/industri di masyarakat Jepara. Sedangkan proses rekrutmen atau seleksi karyawan tidak didasarkan pada lulusan tetapi berdasarkan keterampilan atau skill.

Beberapa penelitian terdahulu yang terkait dengan penelitian ini ditampilkan sebagai pertimbangan untuk memberikan gambaran serta sebagai penjelas kerangka berpikir dalam pembahasan. Pertama, Henkens (2005) melakukan penelitian tentang perekrutan personil dalam bursa lowongan kerja yang kompetitif, sebuah analisis perilaku pekerja dengan menganalisis instrumen-instrumen yang digunakan karyawan untuk berhubungan dengan para pekerja potensial, mengetahui sejauh mana para karyawan mempercayai saranasarana tradsional, dan sejauhmana menggunakan jaringan mendunia, mendatangi bursa kerja dan lain-lain. 
Kedua, Raub (2006) meneliti tentang rekrutmen realistis, studi empiris dalam industri kapal pesiar di industri perkapalan Eropa. Ketiga, Jepsen B. et al (2014) melakukan penelitian literature tentang praktek-praktek rekrutmen di Australia bagi angkatan kerja dan agen-agen tenaga kerja Australia. Keempat, Tong Li (2015) melakukan penelitian tentang rekrutmen tenaga kerja di pabrik Nestle untuk mendeskripsikan pentingnya sumberdaya manusia sebagai sumberdaya utama dalam perusahaan. Hasil rekrutmen tidak hanya berdampak pada kemajuan perusahaan, tetapi juga semacam gambaran tampilan perusahaan itu sendiri, pada saat yang sama bagi pemilik perusaahan juga memiliki peranan vital. Kerja rekrutmen berkualitas berdampak pada titik balik staff dan biaya bisnis, rekrutmen yang efektif membantu perusahaan untuk mendapatkan manfaat kompetitif jangka panjang dan membawa manfaat ekonomi. Selanjutnya, Adebola and Banjo (2017) meneliti tentang prosedur perekrutan dan seleksi serta efektifitas hubungannya dengan kinerja pegawai dalam industri rumah sakit. Keenam, Dewi (2014) meneliti analisis faktorfaktor dan faktor-faktor dominan penyebab anak putus sekolah usia pendidikan dasar dan penyebab anak putus sekolah usia pendidikan dasar. Sodiyah dan Suripno (2016) meneliti upaya dan hambatan pemerintah kabupaten kebumen dalam menanggulangi anak putus sekolah yang ditemui pemerintah kabupaten kebumen dalam menanggulangi anak putus sekolah. Persamaan peneliti ini dengan penelitian-penelitian diatas adalah fokus pada rekrutmen tenaga, dan anak putus sekolah. Adapun perbedaannya adalah penelitian ini dikorelasikan dengan nilai sekolah dan lokasi penelitian di masyarakat industri baru. Penelitian ini bertujuan untuk mendeskripsikan model rekrutmen perusahaan berbasis keterampilan di masyarakat industri Jepara. Berdasarkan latar belakang di atas maka perlu lakukan kajian. Rekrutmen perusahaan merupakan permasalahan yang sangat menarik untuk dikaji karena menyangkut permasalahan umum yang sering kita temukan dalam kehidupan masyarakat, khususnya masyarakat di Kecamatan Mayong yang notabe merupakan masyarakat pedesaan yang berfikir secara primitif dan pragmatis.

\section{Metode Penelitian}

Penelitian ini menggunakan metode survei. Penelitian ini menggunakan teknik total sampling dalam pengambilan sampel dengan menjadikan keseluruhan sampel dari jumlah responden. Angket yang digunakan adalah angket tertutup dan digunakan untuk mengetahui model rekrutmen perusahaan berbasis keterampilan dan dampaknaya pada nilai sekolah di masyarakat industri Jepara. Penelitian ini dilakukan di PT PWI, PT Kanindo, dan PT Jeale Textile wilayah kecamatan Mayong kabupaten Jepara. Penelitian mengambil populasi anak putus sekolah yang diterima bekerja di perusahaan. Teknik pengumpulan data menggunakan angket. Pengolahan data dilakukan dengan menggunakan tabel frekuensi dan dianalisis secara deskriptif kualitatif.

Penelitian ini terdiri dari 3 tahap. Tahap pertama terdapat dua kegiatan berupa observasi ke beberapa perusahaan yang ada di wilayah masyarakat industri Jepara yang akan dijadikan populasi dan sampel dalam penelitian dan studi kasus rekrutmen perusahaan di wilayah masyarakat industri Jepara berdasarkan keterampilan. Hasil dalam tahap pertama berupa deskripsi rekrutmen perusahaan berbasis keterampilan yang ada diwilayah masyarakat industri Jepara. Tahap kedua terdapat dua kegiatan berupa analisis masalah dan analisis kebutuhan hasil langkah ini untuk mendukung dan memperjelas tahap pertama berupa deskripsi model rekrutmen perusahaan berbasis keterampilan di wilayah masyarakat indutri Jepara, dan tahap ketiga terdapat satu kegiatan berupa anasisis data penelitian berupa analisis rekrutmen berbasis keterampilan dan dampaknya pada nilai sekolah di masyarakat industri Jepara. Analisis pada tahap ketiga didasarkan pada hasil langkah pertama dan kedua dengan model analisis deskriptif kualitatif.

Penelitian ini merupakan korelasi penelitian dari Skim PDP pada tahun 2018 yang berjudul "Analisis RPJM Des terhadap anak putus sekolah" dengan objek kajian anak putus sekolah. Penelitian ini tetap pada objek kajian anak putus sekolah hanya saja di korelasikan dan dikembangkan pada rekrutmen perusahaan dan dampaknya pada nilai pendidikan di masyarakat industri Jepara. 
Dalam mengumpulkan data, peneliti menggunakan teknik: (1) dokumentasi, digunakan untuk mengumpulkan data berupa catatan-catatan seperti monografi perusahaan yang didalamnya meliputi data jumlah karyawan, pendidikan karyawan dan tahapan rekrutmen; dan (2) angket, digunakan untuk mengetahui analisis rekrutmen berbasis keterampilan dan dampaknya pada nilai sekolah di masyarakat industri Jepara yang berupa angket tertutup. Dalam pengolahan data, peneliti menggunakan tabel frekuensi. Tabel frekuensi tersebut berisi tentang daftar data penelitian berdasarkan pengelompokan secara runtut demi kemudahan analisis data (Azwar, 2013:123). Data yang dibuat tabel frekuensi adalah hasil angket yang telah diisi responden mengenai rekrutmen berbasis keterampilan dan dampaknya pada nilai sekolah di masyarakat industri Jepara. Teknik analisis data menggunakan deskriptif kualitatif model interaktif (interactive model) Miles dan Hubberman dengan tahapan reduksi data (data reduction), penyajian data (data display), dan penarikan kesimpulan (conclusion drawing) (Sugiyono, 2015: 336-345).

Adapun langkah model interaktif dalam menganalisis data untuk mendeskripsikan analisis rekrutmen berbasis keterampilan dan dampaknya pada nilai sekolah di masyarakat industri Jepara adalah: 1) reduksi data (data reduction) dilakukan dengan mengurangi data yang tidak terkait dengan judul dan topik pembahasan secara proporsional; 2) penyajian data (data display) dilakukan dengan menampilkan data yang sudah pilih dan difilter dan selanjutnya dilakukan kodifikasi data; dan 3) penarikan kesimpulan (drawing conclusion) dilakukan dengan membuat interpretasi data dan membuat kesimpulan sebagai hasil dari penyajian data.

\section{Hasil Penelitian dan Pembahasan}

Secara umum konsep rekrutmen yang diterapkan di PT PWI, PT Kanindo, dan PT Jeale Textile didasarkan pada kebutuhan. Artinya, proses rekrutmen dilaksanakan setelah adanya analisa kebutuhan di tiga perusahaan tersebut akan karyawan baru. Hal ini bertujuan agar tidak terjadi kesalahan dalam perekrutan dan penempatannya. Sebab rekrutmen merupakan langkah awal untuk mendapatkan tenaga kerja terampil dan bermutu. Konsep yang diterapkan ini sejalan dengan apa yang dikemukakan oleh Hasibuan (2010: 40) yakni pengadaan karyawan harus didasarkan pada apa dan siapa. Apa maksudnya perusahaan harus terlebih dahulu menetapkan pekerjaan-pekerjaan yang didasarkan uraian pekerjaan tersebut. Siapa maksudnya artinya perusahaan harus menemukan sosok calon karyawan yang sesuai untuk menempati posisi tertentu sesuai dengan keahlian pekerjaan.

Faktor etos kerja dan kedisiplinan karyawan yang rendah salah satunya disebabkan oleh pemilihan tenaga kerja yang jauh dibawah kompetensi. Jadi, karyawan harus ditugaskan sesuai dengan kemampuan yang dimilikinya dalam memberikan pekerjaan yang sesuai kemampuannya pula. Pada dasarnya pemilihan karyawan di PT PWI, PT Kanindo, dan PT Jeale Textile Jepara tidak jauh berbeda dengan prosedur pemilihan tenaga kerja yang berlaku diperusahaan-perusahaan pada umumnya. Diantaranya adalah (1) Pelamar mengajukan surat lamaran. Dalam hal ini pelamar mengajukan surat lamaran pekerjaan disertai dengan persyaratan-persyaratan yang ditetapkan tiga perusahaan tersebut. Syaratsyarat tersebut adalah foto copy kartu penduduk (KTP), Kartu Keluarga (KK), Surat Keterangan Kelakuan Baik (SKKB) dari kepolisian, ljazah minimal sekolah dasar (SD) sesuai dengan lowongan yang dibutuhkan, Surat keterangan cek kesehatan, dan Umur maksimal 25 tahun. Selain syarat-syarat tersebut, para pelamar juga harus memenuhi persyaratan kepribadian seperti jujur, tanggungjawab, dapat berkomunikasi dengan baik, dan profesional. Menurut kepala personalia dan staf personalia ketiga perusahaan tersebut, syarat-syarat tersebut merupakan syarat utama yang harus dimiliki pelamar. Syarat-syarat tersebut dapat diketahui ketika mereka training kerja dalam tiga bulan. Selain itu dalam menarik karyawan baru PT PWI, PT Kanindo, dan PT Jeale Textile Jepara hanya akan mengambil calon karyawan yang benar-benar memenuhi kriteria yang telah ditentukan. Artinya, sekalipun memiliki saudara atau teman yang menjadi pengurus atau karyawan di perusahaan, karyawan tersebut tidak boleh mengandalkan orang-orang dalam. Demikian juga dengan sistem rekrutmen yang menggunakan sistem merit. Sistem merit adalah penarikan tenaga kerja yang didasarkan pada kemampuan, kecakapan, keterampilan, serta 
pengalaman calon tenaga kerja atau karyawan; (2) Pelaksanaan Tes. Bentuk-bentuk tes yang dilaksanakan di PT PWI, PT Kanindo, dan PT Jeale Textile Jepara adalah tes tertulis dan tes wawancara. Wawancara juga dilakukan sebelum tes tertulis dan setelah tes tertulis. Tujuan pelaksanaan tes-test tersebut adalah untuk mengetahui sejauh mana pengetahuan pelamar terhadap PT PWI, PT Kanindo, dan PT Jeale Textile Jepara, kemampuan pelamar dalam bidang pengetahuan dan administrative, dan Psikologi para pelamar. Rekrutmen yang dilakukan di PT PWI, PT Kanindo, dan PT Jeale Textile Jepara adalah rekrutmen yang selektif karena untuk memperoleh tenaga kerja yang handal harus sesuai dengan standar operasional serta syarat-syarat yang ditetapkan perusahaan. Sedangkan kriteria pendidikan PT PWI, PT Kanindo, dan PT Jeale Textile Jepara dalam mencari tenaga kerja pada dasarnya minimal sekolah dasar sampai perguruan tinggi (SD-S1) dengan persyaratan jujur, loyal, tanggungjawab, dan lain-lain.

Dari hasil wawancara pada obyek studi yang dijelaskan diatas dapat dinyatakan bahwa PT PWI, PT Kanindo, dan PT Jeale Textile Jepara, sistem yang dipakai untuk rekrutmen adalah sistem carier dan sistem meryt, sistem carrier yaitu penarikan tenaga kerja yang didasarkan atas prestasi yang diraih oleh karyawan melalui promosi dan rotasi pekerjaan sedangkan sistem meryt yaitu pengambilan sumber daya karyawan berdasarkan kompetensi, kecakapan, bakat, ketrampilan, kesehatan dan sesuai kriteria yang telah ditentukan sebelumnya, bahwasanya sistem meryt mempunyai keunggulan supaya dalam pemilihan calon karyawan tidak bisa dipengaruhi unsur nepotisme yaitu tidak merekrut tenaga kerja dari pihak. Sumber tenaga kerja yang ada di PT PWI, PT Kanindo, dan PT Jeale Textile Jepara mencakup dua sumber yaitu internal dan eksternal. Sumber internal diambil apabila karyawan yang dimaksud dianggap mempunyai kapasitas yang lebih dan pengalaman yang cukup. Sumber ini dilakukan umumnya untuk pemindahan dan promosi, pemindahan dan promosi dilakukan terhadap karyawan yang menentukanya adalah seorang manager atau pimpinan dari ketiga perusahaan tersebut. Adapun sumber eksternal ditarik apabila betul-betul jabatan yang kosong memang sangat memerlukan tenaga kerja baru, sedangkan dari internal perusahaan sendiri tidak ditemukan sumber daya manusia yang bisa menempati posisi tesebut. Jabatan kosong biasanya terjadi karena kondisi perusahaan yang sangat dinamis, sehingga banyak pekerjaan yang tidak bisa dirapel dan tidak bisa diatasi oleh tenaga manajer yang telah ada.

Dalam mencari calon tenaga kerja menggunakan metode terbuka dan metode tertutup. Metode terbuka adalah metode penyebaran luasan informasi ke masyarakat dengan menempatkan iklan di media masa cetak ataupun elektronik sehingga dibaca oleh masyarakat luas. Tujuan penggunaan metode terbuka adalah supaya banyak direspon banya pembaca dan diharapkan lamaran banyak masuk sehingga kesempatan untuk mendapatkan karyawan yang sesuai kemampuannya lebih besar. Metode tertutup adalah metode pencarian tenaga kerja dengan memberikan informasi lowongan kerja hanya kepada staf atau orang-orang tertentu saja. Hal ini menyebabkan jumlah lamaran yang masuk relative sedikit. Implikasi metode tertutup adalah peluang untuk memperoleh karyawan yang berkualitas lebih sulit.

\section{IV.Kesimpulan}

Berdasarkan hasil dan analisis penelitian, peneliti menyimpulkan bahwa model rekrutmen perusahaan berbasis keterampilan di masyarakat industri Jepara pada PT. PWI, PT Kanindo, dan PT Jeale Textile menggunakan dua model, yaitu model rekrutmen secara internal yaitu dengan menginformasikan adanya lowongan pekerjaan atau jabatan kepada para karyawan yang sudah ada dan menarik tenaga kerja dari internal perusahaan. Keempat perusahaan tersebut telah menerapkan model rekrutmen secara internal sejak tahun 2018 sebagai salah satu pilihan penarikan tenaga kerja. Dalam melaksanakan model rekrutmen ini, perusahaan mengawali dengan pemberian paparan kerja (job description) posisi/jabatan yang ditinggalkan oleh karyawan lama kepada karyawan baru yang lulus pada tahapan rekrutmen internal. Sebagai gambaran, pada tahun 2018 dua orang karyawan dari Divisi Impor dan Ekspor keluar kerja. Maka dari itu Manajer Operasional mendelegasikan masing-masing satu karyawan dari dua divisi tersebut selama kurun waktu tertentu 
menjalankan tugas-tugas pada jabatan tersebut sampai ada staf pengganti yang dapatkan dari proses rekrutmen dan seleksi secara eksternal. Pada dasarnya rekrutmen internal bisa menjadi pemecahan masalah pengisian jabatan yang ditinggalkan oleh tenaga kerja yang mengundurkan diri dari perusahaan sebelum masuknya tenaga kerja pengganti. Menindak lanjuti permsalahan ini, perusahaan diharapkan untuk bisa menentukan tenaga kerja/staf yang cocok dan sesuai untuk menduduki posisi yang ditinggalkan supaya kinerja pada divisi tersebut bisa dipertahankan atau bahkan ditingkatkan.

Model rekrutmen secara eksternal yaitu dengan membuka lowongan pekerjaan di media cetak serta situs web lowongan kerja. PT PWI, PT Kanindo, dan PT Jeale Textile pernah menerapkan model rekrutmen secara ekternal pada tahun 2018 untuk mengisi jabatan kosong, masing masing satu posisi staff pada Divisi Impor dan Ekspor. Berdasarkan hasil wawancara, keempat perusahaan tersebut menjalankan proses rekrutmen akibat ditinggal oleh karyawan yang mengundurkan diri atau pensiun. Maka dari itu, perusahan melakukan tindakan berupa rekrutmen eksternal. Jabatan yang kosong diisi oleh karyawan internal yang diperoleh dari hasil rekrutmen internal. Selanjutnya, perusahaan menjaring calon karyawan baru melalui penyebaran informasi lowongan kerja dengan menggunakan media masa cetak lokal yaitu Suara Merdeka dan Kompas, maupun media eletronik melalui situs web pencari kerja.

Pengaruh model rekruitmen terhadap nilai sekolah adalah bahwa nilai sekolah menjadi sesuatu hal yang tidak terlalu penting karena rekrutmen atau pemilihan karyawan di perusahaan didasarkan pada ketrampilan (skil), bukan pada nilai pada ijasah sekolah. Sedangkan sistem sekolah yang ada saat ini lebih menekankan pada nilai ijasah. Tidak adanya link and match (sinergi) antara perusahaan dan sekolah dalam hal persyaratan kompetensi lulusan sekolah yang notabene menjadi sumber tenaga kerja. Komptensi lulusan tidak sesuai dengan kompetensi yang disyaratkan oleh perusahaan.

\section{Daftar Pustaka}

Adebola and Banjo. (2017). Recruitment and Selection Procedures and Their Relative Effectiveness on Employees' performance in the Hospitality Industry in Ogun State. An International Journal of Business and Management Studies Vol 5, No 1.

Azwar. Saifuddin. (2013). Metode Penelitian. Yogyakarta: Pustaka Pelajar.

Beeby, C.E. (1991). Pendidikan di Indonesia. Jakarta: Penerbit LP3ES.

Denise Jepsen B. et al. (2014). Australian Recruitment Practices: A Literature Review on Current Australian Recruitment Practices for Australian Workforce and Productivity Agency. Macquarie: Macquarie University.

Dewi, Ni Ayu Krisna. (2014). "Analisis Faktor-faktor Penyebab Anak Putus Sekolah Usia Pendidikan Dasar Kecamatan Gerokgak Tahun 2012/2013.” Jurnal Undiksha Vol. 1, No. 1. ISSN 0215-8250. ejournal.undiksha.ac.id.

Fisher et.al. (2006). Human Resourches Management, $2^{\text {nd }}$ edition. Boston: Houghton Mifflin.

Hasibuan, Malayu S.P. 2010. Manajemen Sumber Daya Manusia. Jakarta: PT Bumi. Aksara.

Henkens, Ke`ne. (2005). Recruiting personnel in a tight labour market: an analysis of employers' behavior. An International Journal of Manpower Vol. 26 No. 5 Vol. 26 
No. 5 pp 421-433. Diaksesdihttp://ejournal.undiksha.ac.id/index.php/JJP E/articel/viewFile/1898/1650.pdf. diunduh pada tanggal 18 Agustus 2018.

Mondy R. Wayne. (2008). Manajemen Sumber Daya Manusia, edisi kesepuluh, jilid 1. Jakarta: Erlangga

Musfiqon. (2007). Menangani yang Putus Sekolah. http://www.surya.co.id/web/opini/menangani-yang putus-sekolah.html.

Noe, Raymond A, et al. (2000). Human Resources Management: Gaining a Competitive Advantage. $3^{\text {rd }}$ edition. Boston, Massachusetts: The McGraw-Hill Companies, Inc

Rachmawati, Kusdyah. (2008). Manajemen Sumber Daya Manusia, Yogyakarta: ANDI.

Raub, Steffen. (2006). Realistic recruitment: An empirical study of the cruise industry. Journal of Contemporary Hospitality Management. Retrieved from www.emeraldinsight.com/0959-6119.htm

Sodiyah dan Suripno. (2016). Upaya Pemerintah Kabupaten Kebumen dalam Menanggulangi Anak Putus Sekolah. Jurnal Pendidikan Kewarganegaraan dan Hukum. Jurnal.usu.ac.id. 2014 ISSN: 2549-130

Sugiyono. (2015). Metode Penelitian Pendidikan: Pendekatan Kuantitatif, Kualitatif, dan $R \& D$. Bandung: Penerbit Alfabeta

Tong Li. (2015). Nestle Employee Recruitment Research. International Journal of Business and Social Science. Vol. 6, No. 4(1) Retrieved from: https://www.ijbssnet.com

Yusuf, A. Muri. (2000). Pengantar IImu Pendidikan, Edisi III. Jakarta: Balai Aksara. 